American Journal of Applied Sciences 8 (4): 393-399, 2011

ISSN 1546-9239

(C) 2010 Science Publications

\title{
On the Influence of Stator Slot shape on the Energy Conservation Associated with the Submersible Induction Motors
}

\author{
M. Sundaram and P. Navaneethan \\ Department of Electrical and Electronics Engineering, PSG College of Technology, \\ Avinashi Road, Coimbatore-641 004, Tamilnadu, India
}

\begin{abstract}
Problem statement: A good design of Submersible Induction Motor is required to maintain maximum efficiency level. This can be achieved in one way by optimum design of magnetic circuit. The magnetic circuit of an Induction Motor is formed by the combination of Stator core, Rotor core and air gap. In applications like Submersible Motor Pumps, the air gap cannot be minimized beyond $0.5 \mathrm{~mm}$, because of the machining tolerance required, due to large core length. Now a day, the efficiency of such motor is improved by die-cast copper rotor. But the cost of such motor is more and sometimes the rotor core properties are getting changed due to high temperature during die- casting process. Approach: A new stator slot shape is proposed based on the results obtained from the iterations with Rotational Machine Expert (RMxprt) software and the performance is compared with that of the existing stator slot shape, for a 3-phase, $5 \mathrm{hp}, 380 \mathrm{~V}$, 2-pole motor The motor with both the stator slot shapes have been analyzed with the Rotational Machine Expert (RMxprt) software. Results: The magnetizing current of new design is $3.25 \mathrm{~A}$, compared to the existing design of $4.67 \mathrm{~A}$. The overall efficiency of the Submersible Induction Motor pump set is 5\% more than that of the existing one. The discharge of the pump set has increased by about 80 liters per minute. Conclusion: The proposed stator slot dimension is suitable for more efficiency, less magnetizing current and a good power factor. This design modification does not require much cost and needs no complex manufacturing process.
\end{abstract}

Key words: Submersible induction motor, optimum design, magnetic circuit, rotational machine, magnetizing current, power factor, electrical energy, electric machines, genetic algorithms, stator slot

\section{INTRODUCTION}

Submersible Induction Motor with the pump sets are extensively used for agriculture and domestic purposes, owing to their simplicity, ruggedness and low cost. In India, during this decade, most of the Submersible Induction Motors are being manufactured with smaller frame size, due to increasing material cost, increasing labor cost and to provide economical model. But, this is at the expense of efficiency, large magnetizing current and poor operating power factor. In order to maximize the efficiency and consequently minimize the electrical energy consumption of a 3Phase Submersible Induction Motor, many optimization techniques have been used and suggested in the published literature. The corresponding objective function is generally employed for an economic manufacturing of motors. Such a research effort was undertaken before the energy crisis in 1973. Since then, trend of optimum design has changed; in fact efficiency and consumed electrical energy appear to be more important than in the past.

Many works have concentrated upon this type of design ( Mujal-Rosas and Boix-Aragones, 2007, Hakiki Khalid et al., 2007 ) A combination of efficiency and cost objective functions is possible and efficiency-cost objective function can partly benefit from the advantages of the efficiency and cost optimum design (Cistelecan et al., 2009).

An attempt has been made to use two optimization techniques simultaneously for different aims as described in (Frauman et al., 2007), but again for efficiency optimization of the motor. (Subramanian et al., 2010), two optimization techniques (Powell and boundary search around active constraints methods) have been compared. Two other techniques, simplex and Hooke-Jeeves methods have been compared Application of genetic algorithms for the design

Corresponding Author: M. Sundaram, Department of Electrical and Electronics Engineering, PSG College of Technology, Avinashi Road, Coimbatore-641 004, Tamilnadu, India 
Am. J. Applied Sci., 8 (4): 393-399, 2011

optimization of electric machines has been tested in Other aspects in the design of Induction Motor have been introduced in (Mahdi S et al., 2009, Lubis et al., 2009). A further contribution is the optimum design of a three- phase Induction Motor, using three objective functions, namely Efficiency (E), Cost (C) and a combined objective function of Efficiency-Cost (EC). A design package has been developed specifically for a 3 - phase squirrel-cage type Induction Motor. A unique search routine of Hooke - Jeeves is then used for the three optimization processes. In many investigations, it is found that the solutions or suggestions given by optimization techniques are for Induction Motor only; but these suggestions are not suitable for manufacturing a Submersible Induction Motor, because of the limitations in $\mathrm{D} / \mathrm{L}$ ratio, the technological complexity in design and manufacturing tools and cost.

The aim of this study is to present the results of performance comparison of a 3-phase, $5 \mathrm{hp}, 380 \mathrm{~V}$, 2Pole Submersible Induction Motor with two different stator slot shapes. A $5 \mathrm{hp}$ Submersible Induction Motor, having specifications shown in Table 1, has been chosen for comparison with two different stator slot shapes. The basic specifications of these designs are similar and the same constraints are imposed upon the design process. Design package software namely RMxprt from ANSOFT Corporation has been used specifically to determine the optimum stator slot shape, which consumes less magnetizing current. Simulated Steady-state performance characteristics of the motor have been plotted for comparison. The motor has been manufactured with two different stator slot shapes and have been tested by applying pump load and the performance characteristics have been plotted for comparison. The proposed stator slot shape is advantageous in respect of magnetizing current, efficiency, power factor and slip.

\section{MATERIALS AND METHODS}

For analysis in RMxprt, a 3-phase Submersible Induction Motor model has been selected with the specifications as shown in Table 1.

With all other motor specifications (Stator dimensions, Rotor dimensions and winding details) remaining the same, the motor has been simulated with two different stator slot shapes. One of these types is an existing type and the other being the proposed shape based on the results obtained from the iterations with Rotational Machine Expert (RMxprt) software, with the objective of minimizing the magnetizing current and to improve the efficiency.
Table 1: Motor specifications

\begin{tabular}{ll}
\hline Parameter & Value \\
\hline Output power ( $\mathrm{P}_{\mathrm{o}}$ ) & $5 \mathrm{hp}$ \\
Rated voltage (V) & $380 \mathrm{~V}$ \\
Winding connection & Wye \\
Number of poles (P) & 2 \\
Rated speed (Nr) & $2880 \mathrm{rpm}$ \\
Frequency (f) & $50 \mathrm{~Hz}$ \\
Type of load & Constant power \\
Operating temperature (T) & $75{ }^{\circ} \mathrm{C}$ \\
Inner diameter of the stator (Dsi) & $73 \mathrm{~mm}$ \\
Outer diameter of the stator (Dso) & $137 \mathrm{~mm}$ \\
Length of the stator core & $150 \mathrm{~mm}$ \\
Outer diameter of the rotor (Dro) & $71.6 \mathrm{~mm}$ \\
Inner diameter of the rotor (Dri) & $42 \mathrm{~mm}$ \\
End ring width (We) & $5 \mathrm{~mm}$ \\
End ring length (Le) & $1 \mathrm{~mm}$ \\
End ring height (He) & $3 \mathrm{~mm}$ \\
Number of stator slots (Ss) & 24 \\
Number of rotor slots (Rs) & 18 \\
Conductors per slot (Zss) & 31 \\
\hline
\end{tabular}

Table 2: Dimensions of existing slot

\begin{tabular}{lc}
\hline Dimension of stator slot & Values $(\mathrm{mm})$ \\
\hline Hs0 & 1.00 \\
Hs1 & 0.80 \\
Hs2 & 15.80 \\
Bs0 & 4.00 \\
Bs1 & 5.10 \\
Bs2 & 8.32 \\
Rs & 1.00 \\
\hline
\end{tabular}

Table 3: Dimensions of proposed slot

\begin{tabular}{ll}
\hline Dimension of stator slot & Values $(\mathrm{mm})$ \\
\hline Hs0 & 1.0 \\
Hs1 & - \\
Hs2 & 6.3 \\
Bs0 & 4.0 \\
Bs1 & 5.1 \\
Bs2 & 6.8 \\
Rs & 1.0
\end{tabular}

Stator slot configurations:

Existing slot: Table 2 shows the dimensions of the existing slot and the shape is shown in Fig. 1.

Proposed slot: Table 3 shows the dimensions of the proposed slot and the corresponding shape is shown in Fig. 2.

M-47 steel has been chosen as the stamping material and the number of stator slots being 24, the stator stamping is formed in RMxprt with both the existing slot and the proposed slot. Figure 3 shows the RMxprt view of stator stampings for both the slots.

Keeping the shape and the number of rotor slots same for both the type of stator slots, the Induction Motor assembly has been formed. The assemblies of the respective motor models are shown in Fig. 4. 
Am. J. Applied Sci., 8 (4): 393-399, 2011

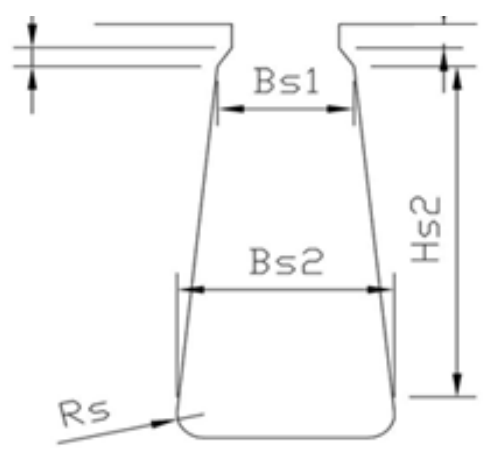

Fig. 1: Shape of the existing slot

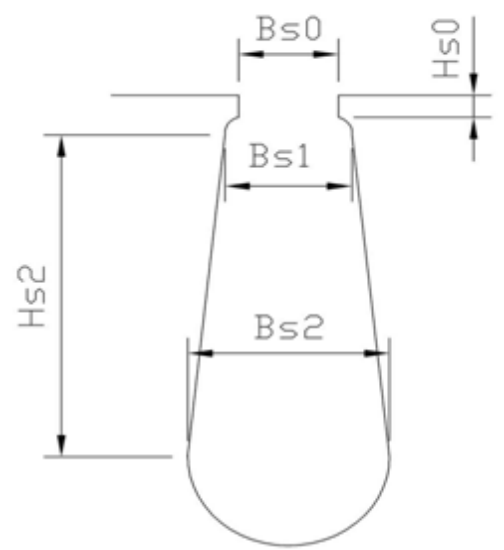

Fig. 2: Shape of the proposed slot

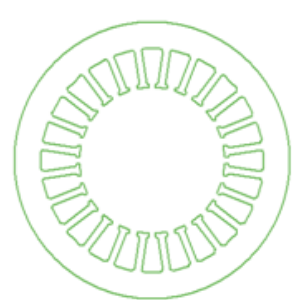

(a)

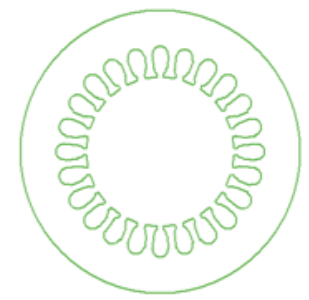

(b)
Fig. 3: (a) Stamping of the Existing Slot, (b) Stamping of the Proposed Slot

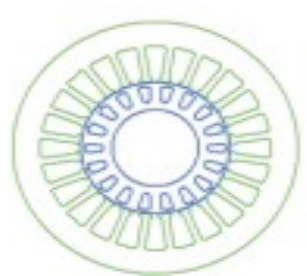

(a)

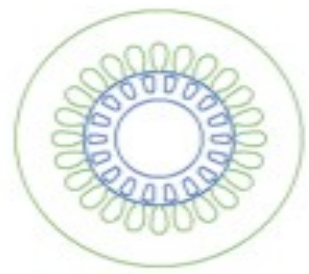

(b)
Fig. 4: (a) Motor Assembly of the Existing Slot, (b) Motor Assembly of the Proposed Slot
ROTATIONAL machine expert: RMxprt is an interactive software package from ANSOFT Corporation used for the design and analysis of electrical machines. Using RMxprt, following types of electrical machines can be modeled, simulated and analyzed:

- 3-phase and 1 -phase Induction Motors

- Permanent-Magnet DC Motors

- Switched Reluctance Motors

- General DC Motors and Generators

\section{RESULTS}

With the fixed operating conditions, the machine has been simulated in RMxprt and the result is tabulated as shown in Table 4. The performance curves have been obtained for both the stator slot types

Following inferences have been made from Table 4:

- The motor with proposed slot consumes less magnetizing current and found power factor is improved

- The stator phase current of motor with proposed slot is less when compared to that in a motor with existing slot

- The efficiency of the motor with the proposed slot is significantly improved

- The operating slip of the motor is reduced in good amount

- The stator resistance of the proposed slot shape is being less, due to the less over hang portion of the winding

Table 4: Performance Comparison of Motor with two different slot

\begin{tabular}{lll}
\multicolumn{1}{c}{ shapes } & $\begin{array}{l}\text { Motor with the } \\
\text { existing slot }\end{array}$ & $\begin{array}{l}\text { Motor with the } \\
\text { proposed slot }\end{array}$ \\
\hline Attributes & $2.46 \Omega$ & $2.12 \Omega$ \\
\hline Stator resistance & $2.70 \Omega$ & $2.16 \Omega$ \\
Stator leakage reactance & $2.89 \Omega$ & $2.89 \Omega$ \\
Rotor resistance & $7.07 \Omega$ & $7.94 \Omega$ \\
Rotor leakage reactance & $679.10 \Omega$ & $1117.3 \Omega$ \\
Resistance corresponding & & \\
to iron-core loss & $39.48 \Omega$ & $57.33 \Omega$ \\
Magnetizing reactance & $10.88 \mathrm{~A}$ & $9.10 \mathrm{~A}$ \\
Stator phase current & $4.67 \mathrm{~A}$ & $3.26 \mathrm{~A}$ \\
Magnetizing current & $8.24 \mathrm{~A}$ & $7.95 \mathrm{~A}$ \\
Rotor phase current & $877.63 \mathrm{~W}$ & $526.67 \mathrm{~W}$ \\
Copper loss of stator winding & $590.03 \mathrm{~W}$ & $547.96 \mathrm{~W}$ \\
Copper loss of rotor winding & $150.18 \mathrm{~W}$ & $93.64 \mathrm{~W}$ \\
Iron-core loss & $8.13 \mathrm{~W}$ & $8.13 \mathrm{~W}$ \\
Frictional and wind loss & $1625.97 \mathrm{~W}$ & $1176.40 \mathrm{~W}$ \\
Total loss & $5.32 \mathrm{~kW}$ & $4.87 \mathrm{~kW}$ \\
Input power & $3.72 \mathrm{~kW}$ & $3.73 \mathrm{~kW}$ \\
Output power & $13.74 \mathrm{Nm}$ & $12.33 \mathrm{Nm}$ \\
Mechanical shaft torque & $69.55 \%$ & $76.59 \%$ \\
Efficiency & 0.74 & 0.81 \\
Power factor & $8.3 \%$ & $4.5 \%$ \\
Rated Slip & $2750.35 \mathrm{rpm}$ & $2865.71 \mathrm{rpm}$ \\
Rated Shaft Speed & & \\
\hline
\end{tabular}


Am. J. Applied Sci., 8 (4): 393-399, 2011

Equivalent circuit: The equivalent circuits for the Submersible Induction Motor with both the type of slots have been derived with the help of the obtained simulation results. The improvement in efficiency and power factor for the motor with the proposed slot can be attributed to the decrease in the magnetizing current. The modification in the geometry of the slot has resulted in higher impedance of the stator core, in comparison with the existing slot, resulting in decreased magnetizing current; these facts can be visualized from Fig. 5-6.

The simulation results of the motors with both the stator slot shapes have been presented in the Fig. 7-8. The load current and the efficiency of the proposed stator slot shape have been found improved.

The design variables are specified along with its bounds in Table 2-6 bits are encoded for each continuous.

Here all the constraints cannot be directly described in terms of design variables; hence, they are implicit and their calculation requires analyzing the motor.

GA is ideally suited for unconstrained optimization problems (Subramanian et al., 2010)). As the present problem is a constrained optimization one, it is necessary to transform it into an unconstrained problem to solve it using GA (Sendil and Nagarajan, 2009).

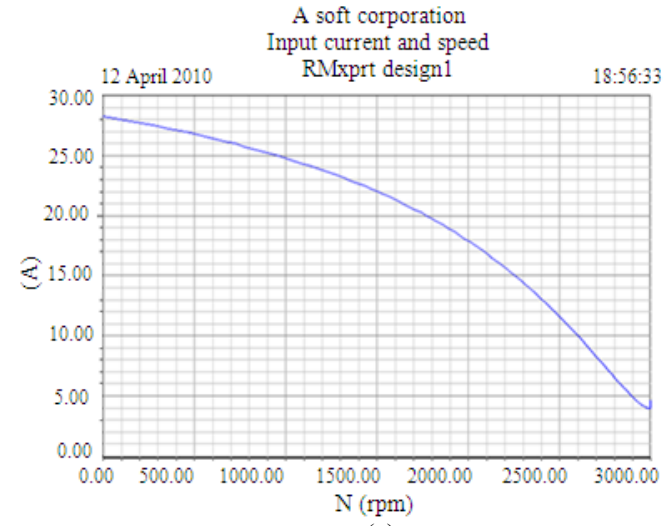

(a)

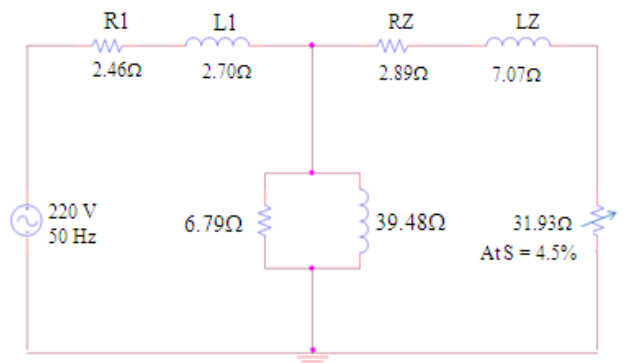

Fig. 5: Equivalent Circuit of the Motor with the existing stator slot

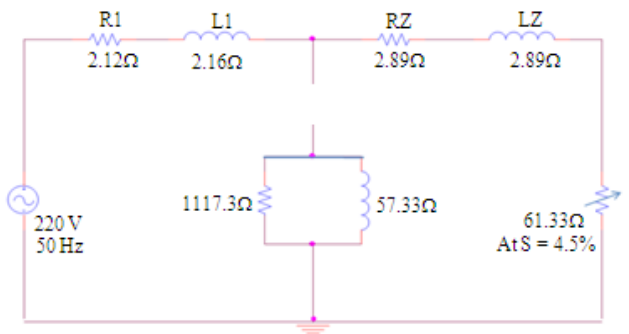

Fig. 6: Equivalent Circuit of the Motor with the proposed stator slot

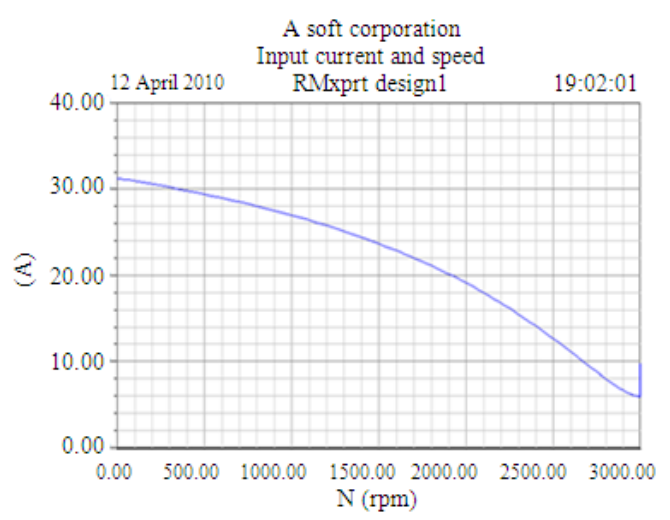

(b)

Fig. 7: Load current Vs speed (a) For the Proposed stator slot shape, (b) For the Existing stator slot shape

Table 5: Load test performance of submersible induction motor with existing slot shape

\begin{tabular}{|c|c|c|c|c|c|c|c|c|c|c|}
\hline S.No. & $\begin{array}{l}\text { Speed } \\
(\mathrm{rpm})\end{array}$ & $\begin{array}{l}\text { Delivery gauge } \\
\text { reading }\left(\mathrm{kg} \mathrm{m}^{-2}\right)\end{array}$ & $\begin{array}{l}\text { Total } \\
\text { head }(\mathrm{m})\end{array}$ & $\begin{array}{l}\text { Rise in } \\
\operatorname{tank}(\mathrm{cm})\end{array}$ & $\begin{array}{l}\text { Rise } \\
\text { Time (s) }\end{array}$ & $\begin{array}{l}\text { Discharge } \\
(\mathrm{lpm})\end{array}$ & $\begin{array}{l}\text { Currrent } \\
\text { (A) }\end{array}$ & $\begin{array}{l}\text { Power } \\
(\mathrm{kW})\end{array}$ & $\begin{array}{l}\text { Pump } \\
\text { output }(\mathrm{kW})\end{array}$ & $\begin{array}{l}\text { Overall } \\
\text { efficiency }(\%)\end{array}$ \\
\hline 1 & 2848 & 0.00 & 1.53 & 30.00 & 47.46 & 383 & 9.37 & 4.63 & 0.10 & 2.10 \\
\hline 2 & 2843 & 2.00 & 21.41 & 30.00 & 53.81 & 338 & 9.63 & 4.84 & 1.21 & 25.01 \\
\hline 3 & 2844 & 4.00 & 41.27 & 30.00 & 66.06 & 275 & 9.63 & 4.87 & 1.90 & 38.93 \\
\hline 4 & 2851 & 5.00 & 51.22 & 30.00 & 74.34 & 244 & 9.47 & 4.73 & 2.08 & 44.05 \\
\hline 5 & 2864 & 6.00 & 61.15 & 30.00 & 90.15 & 201 & 9.20 & 4.59 & 2.05 & 44.53 \\
\hline 6 & 2875 & 7.00 & 71.07 & 20.00 & 85.38 & 142 & 8.47 & 4.01 & 1.67 & 41.64 \\
\hline 7 & 2896 & 7.50 & 76.02 & 10.00 & 76.41 & 79 & 7.53 & 3.21 & 1.00 & 31.26 \\
\hline 8 & 2929 & 7.90 & 80.00 & 0.00 & 0.00 & 0 & 6.37 & 2.23 & 0.00 & 0.00 \\
\hline
\end{tabular}

396 
Am. J. Applied Sci., 8 (4): 393-399, 2011

Table 6: Load test performance of submersible induction motor with proposed slot shape

\begin{tabular}{|c|c|c|c|c|c|c|c|c|c|c|}
\hline S. No. & $\begin{array}{l}\text { Speed } \\
(\mathrm{rpm})\end{array}$ & $\begin{array}{l}\text { Delivery gauge } \\
\text { reading }\left(\mathrm{kg} \mathrm{m}^{-2}\right)\end{array}$ & $\begin{array}{l}\text { Total } \\
\text { head }(\mathrm{m})\end{array}$ & $\begin{array}{l}\text { Rise in } \\
\operatorname{tank}(\mathrm{cm})\end{array}$ & $\begin{array}{l}\text { Rise } \\
\text { time (s) }\end{array}$ & $\begin{array}{l}\text { Discharge } \\
(\mathrm{lpm})\end{array}$ & $\begin{array}{l}\text { Current } \\
\text { (A) }\end{array}$ & $\begin{array}{c}\text { Power } \\
(\mathrm{kW})\end{array}$ & $\begin{array}{l}\text { Pump } \\
\text { output }(\mathrm{kW})\end{array}$ & $\begin{array}{l}\text { Overall } \\
\text { efficiency }(\%)\end{array}$ \\
\hline 1 & 2872 & 0.00 & 1.76 & 30.00 & 39.53 & 460 & 8.40 & 4.38 & 0.13 & 2.99 \\
\hline 2 & 2867 & 2.00 & 21.57 & 30.00 & 45.64 & 399 & 8.87 & 4.52 & 1.44 & 30.75 \\
\hline 3 & 2869 & 4.00 & 41.36 & 30.00 & 57.83 & 315 & 8.83 & 4.56 & 2.17 & 46.13 \\
\hline 4 & 2876 & 5.00 & 51.28 & 30.00 & 65.56 & 277 & 8.90 & 4.44 & 2.36 & 51.81 \\
\hline 5 & 2885 & 6.00 & 61.19 & 30.00 & 80.15 & 226 & 8.57 & 4.32 & 2.30 & 51.97 \\
\hline 6 & 2913 & 7.00 & 71.09 & 20.00 & 76.48 & 158 & 7.30 & 3.68 & 1.86 & 49.53 \\
\hline 7 & 2930 & 7.50 & 76.03 & 10.00 & 69.51 & 87 & 6.63 & 2.84 & 1.10 & 37.76 \\
\hline 8 & 2959 & 7.90 & 80.00 & 0.00 & 0.00 & 0 & 5.17 & 1.96 & 0.00 & 0.00 \\
\hline
\end{tabular}

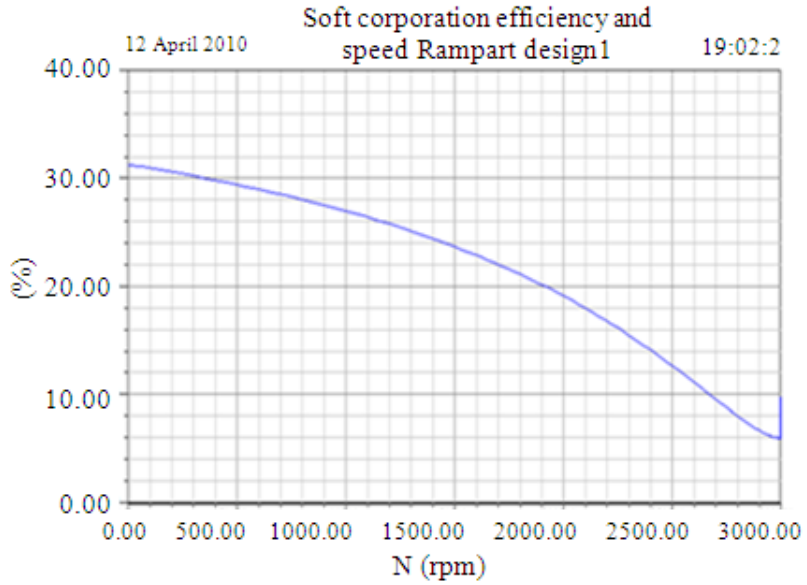

(a)

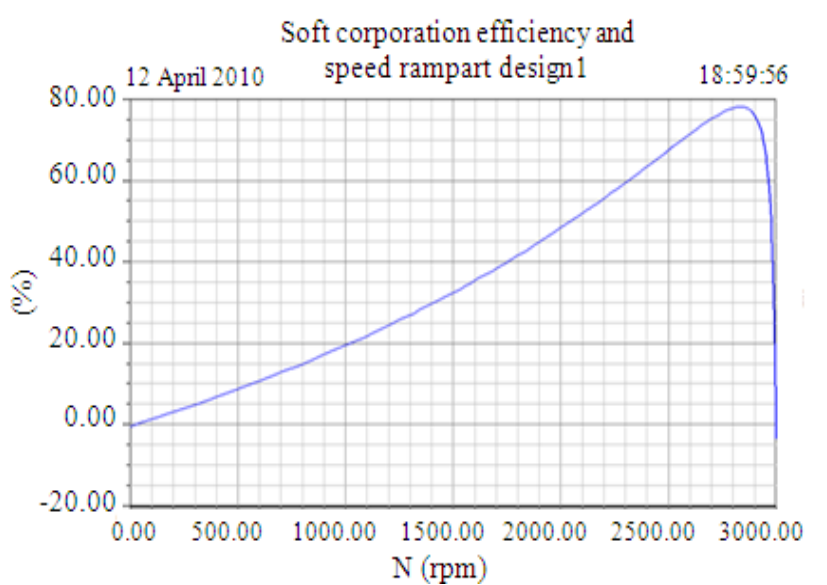

(b)

Fig. 8: Efficiency $V_{s}$ speed (a) For the Proposed stator slot shape (b) For the Existing stator slot shape

Since GA perform the search in parallel using population of points in the search space, a formulation based on the violations of normalized constraints is used. It is expressed as follows:

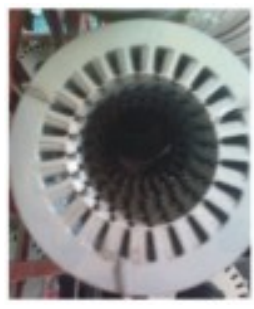

Fig. 9: Existing stator stamping

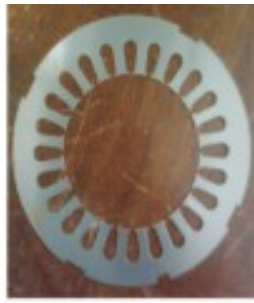

Fig. 10: Proposed stator stamping
Bta s,r/Btp s,r-1 $\leq 0$; Bca s,r/Bcp s,r-1 $\leq 0$

Real-time implementation and results: The Submersible Induction Motors with both the stator slot shapes have been manufactured and the load test has been conducted with a 6" pump. The respective stator stampings are shown in Fig. 9-10 and their corresponding test setups are shown in Fig. 11-15.

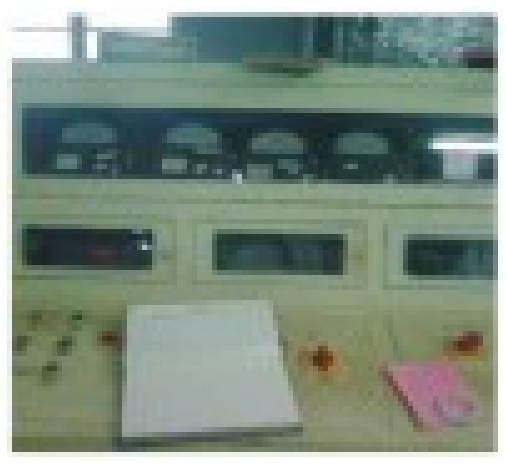

Fig. 11: Testing panel 


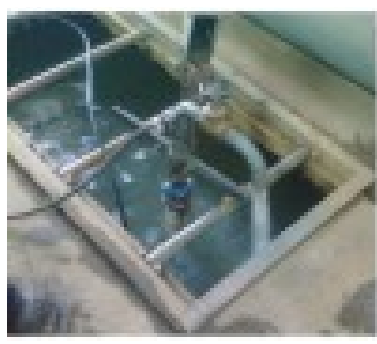

Fig. 12: Pump loading

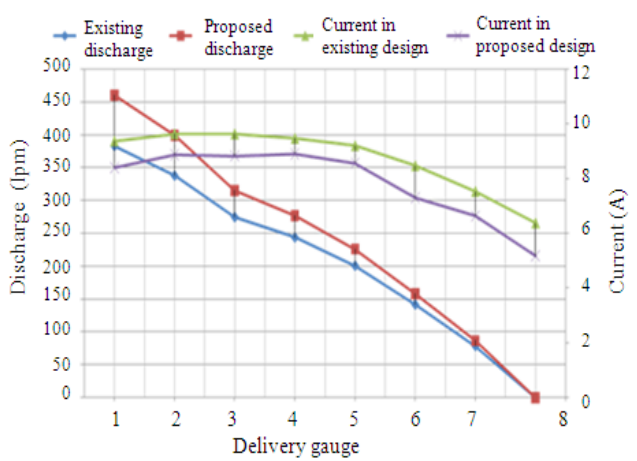

(a)

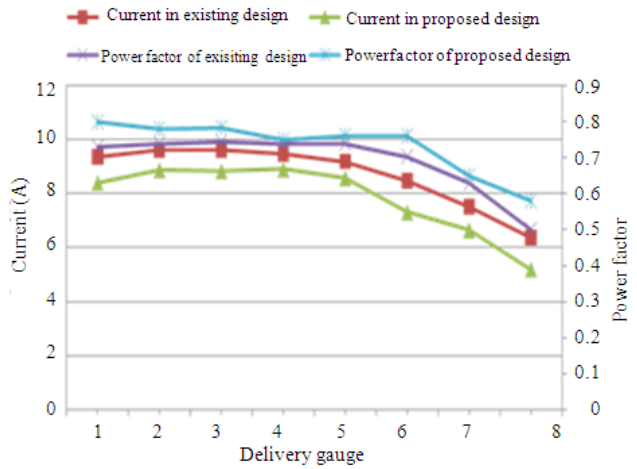

(b)

Fig. 13: Performance Comparison curve (a) Discharge, (b) Current and Power factor

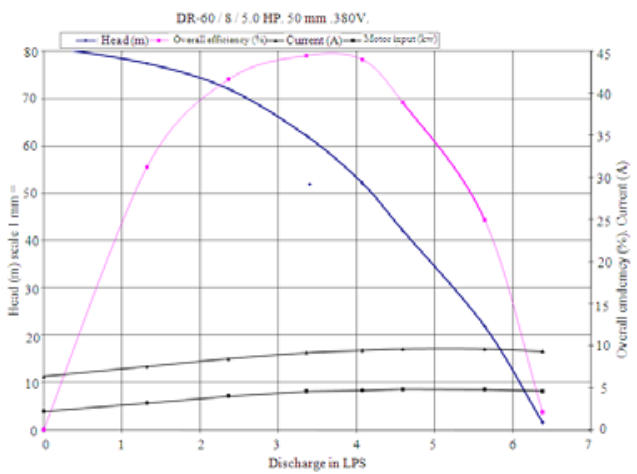

Fig. 14: Pump Performance curve for existing slot shape

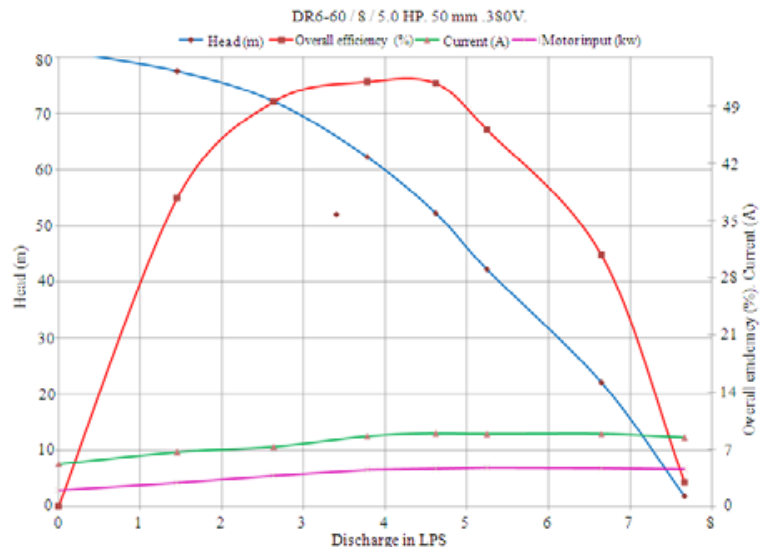

Fig. 15: Pump Performance curve of proposed slot shape

\section{DISCUSSION}

The proposed stator slot consumes less magnetizing current as $3.26 \mathrm{~A}$, compared to the existing one with the current of $4.67 \mathrm{~A}$. This results improved power factor, pump out put with more discharge and efficiency. The slip of the motor is also reduced. The losses in the proposed motor are considerably reduced. The volume of the material and copper consumption is also reduced.

\section{CONCLUSION}

This study has compared 3-phase Submersible Induction Motors with a two different stator slot shapes of the same rating. A $5 \mathrm{hp}$ motor has been designed as an illustrative example. On the basis of the results obtained, one may conclude the following:

- The new design has resulted in a lower magnetizing current, higher efficiency, good operating power factor and less drop in speed

- The overall efficiency of the Submersible Induction Motor pump set is 5\% more than that of the existing one

- The discharge of the pump set has increased by about 80 liters per minute

- The cost involved in the proposed design is same as that of the existing one; the technological complexity involved in manufacturing is less

\section{ACKNOWLEDGEMENT}

The researchers express their gratitude to the DECCAN Industries, Coimbatore and PSG Industrial Institute, Coimbatore, for supporting this study. Additionally, the authors would like to thank 
Mr.V.Jeyaprakash, Design Engineer, TEXMO Industries, Coimbatore, for providing consultancy and the necessary help in using RMExprt software for the simulations.

\section{REFERENCES}

Cistelecan, M.V, H.B. Cosan and M. Popescu, 2009. Part-winding starting improvement of three-phase squirrel-cage induction motor. Proceedings of the 8th International Symposium on Advanced Electromechanical Motion Systems and Electric Drives Joint Symposium, July 1-3, IEEE Xplore, Lille, $\quad$ pp: $1-6 . \quad$ DOI: 10.1109/ELECTROMOTION.2009.5259141

Frauman, P., A. Burakov and A. Arkkio, 2007. Effects of the slot harmonics on the unbalanced magnetic pull in an induction motor with an eccentric rotor. IEEE Trans. Magne., 43: 3441-3444. DOI: 10.1109/TMAG.2007.899470
Khalid, H., M. Benyounès and D.S. Ahmed, 2007. Induction motor flux estimation using nonlinear sliding observers. J. Math. Stat., 3: 65-69. DOI: 10.3844/jmssp.2007.65.69

Lubis, Z., A.N. Abdalla, Mortaza and R. Ghon, 2009. Mathematical modeling of the three phase induction motor couple to dc motor in hybrid electric vehicle. Am. J. Eng. Applied Sci., 2: 708-712. DOI: 10.3844/ajeassp.2009.708.712

Mujal-Rosas, R. and O. Boix-Aragones, 2007. Improvement of the three-phase induction motor with spiral sheet rotor. Proceedings of the IEEE International Symposium on Industrial Electronics, June 4-7, IEEE Xplore, Vigo, pp: 1107-1112. DOI: 10.1109/ISIE.2007.4374753

Subramanian, R., S.N. Sivanandam and C. Vimalarani, 2010. An optimization of design for s4-duty induction motor using constraints normalization based violation technique. J. Comput. Sci., 6: 107-111. DOI: $10.3844 /$ jcssp.2010.107.111 